Bulletin of Taras Shevchenko National University of Kyiv. Series "Psychology". № 1(10), pp. 10-13 (2019) УДК 159.9

DOI: https://doi.org/10.17721/BSP.2019.1(10).2
ISSN 1728-3817

(C) Taras Shevchenko National University of Kyiv, Publishing Center "Kyiv University", 2019

Irina Astremskaya, PhD, Assoc. Prof. Taras Shevchenko National University of Kyiv, Kyiv, Ukraine

\title{
FEATURES OF EMOTIONAL BURNOUT BY SPECIALISTS IN ASSISTING PROFESSIONS
}

The article deals with the problem of "professional exit", which is referred to as "professional benefits" in the activities of specialists professionals. The peculiarities of professional activity of teachers and psychologists of educational institutions, which complicate the work of the specified category of specialists, are considered. Particular attention is paid to the syndrome of "professional burnout" among pedagogical workers of educational institutions for children with physical and psychiatric disabilities due to the fact that their professional activities are deeply. Specific and emotionally tense.

Keywords: professional burnout syndrome, psychological protection, teacher, vocational assistance.

Formulation of the problem. The problem of "burnout" of staff attracts more attention in medical, organizational and special psychology. This is primarily due to increased requirements for professional activity. A modern specialist must not only know the subject of his work, possess information technologies, but also have the appropriate professional qualities, including developed communication skills (communication skills with people), high efficiency, self-control and balance, activity and initiative, organizational and analytical abilities, flexibility and so on.

But the high demands placed on the personality of a specialist often do not correspond to the conditions in which his activity takes place (conditions of the material environment, socio-psychological conditions). In addition, there are personal qualities that make the subject more vulnerable to the syndrome of "burnout".

Among them: the desire for imminent success, hyperresponsibility; the presence of a small number of interests in addition to work or their absence [7]; the prevalence of internal control locus, low self-esteem, anxiety, aggressiveness [6], and others.

The consequences of this process are the formation of constantly acting stress situations, and if a person does not have the skills to overcome stress, then the last phase of overexertion - the phase of exhaustion - develops with pathological manifestations, in particular as a syndrome of "burnout".

Particularly inclined to burn out those people who must "give" people energy and warmth of the soul: teachers, psychologists, doctors, artists.

With prolonged burnout, stress develops with such characteristic symptoms as cardiovascular disorders, neuroses, stomach ulcers, weakening of immunity, and so on. Growing up "professional cynicism", negativism in relation to their work. Sometimes there is disgust at all, unmotivated images of others, fate, government. Life seems empty and meaningless, and work is a sham and hateful routine. People with whom they have to work are particularly disliked. Such kind of burnout is even called "human poisoning".

Burning is partly a functional stereotype, because it allows a person to dosage and economically spend energy resources. At the same time, there may be dysfunctional consequences, when burnout negatively affects the performance of professional activities and relations with a partner (the object of professional activity). Our nervous system has some "communication limit", if it is exceeded, inevitably comes an exhaustion, and eventually burnout. The same limit exists for other mental processes (perception, problem solving, attention, etc.). This limit is quite mobile, it affects the tone of the nervous system, as well as unresolved problems, lack of sleep and many other factors. In addition, communicating with people is a two-way process.

Analysis of recent research and publications. $\mathrm{H}$. J. Freidenberger, author of the idea of burnout, believes that professional burnout is an exhaustion of energy from professionals working in the field of social assistance when they feel overwhelmed by other people's problems. This, he argues, is accompanied by the emergence of a cynical guideline - "Why worry? It does not matter". When an employee is "extinguished" for any reason, he becomes an inefficient worker and loses much effort to achieve the goal.

The term "burnout" is an inaccurate metaphor, although today it is a recognized and universally applicable psychological appellation.

Instead, the scientist argues that this is "a new name of the old problem" - the general name of the consequences of prolonged work stress and a certain kind of professional crisis. Since the data of modern studies have clearly shown that burnout can be distinguished from other forms of stress both conceptually and empirically, and therefore it is not just a synonym, there is a need for systematic scientific research of the phenomenon of "professional burnout".

Recently, foreign and domestic scientists began to actively explore the phenomenon of "professional burnout". Among them - M. Burish, G. Dion, L. M. Karamushka, N. O. Levitskaya, G. V. Lozhkin, M. P. Leiter, S. D. Maksimenko, L. Malets, E. Maher, V. E. Orel, M. L. Smulson, T. V. Formanyuk, H. J. Freidenberger, U. B. Shufely, etc.

Numerous foreign studies have confirmed the relationship between emotional burn-out and age-related subjects (L. C. Dietzel, R. D. Coursey, E. S. Huebner, J. S. Oktay, C. VanWijk, etc.), male affiliation (R. J. Burke, E. Greengalass), family status (J. Daniel, I. Shabo,

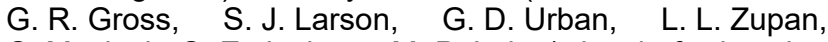
C. Maslach, S. E. Jackson, M. P. Leiter), level of education (W. B. Schaufeli, D. Enzmann), job satisfaction (R. J. Burke, J. De Jonge).

Individual factors of the emergence of emotional burnout are highlighted in the works of foreign psychologists, namely N. Tollefson, R. T. Lee, B. E. Ashforth, C. M. Pierce, G. N. Molloy link it with individual strategies for resistance to stressful situations; B. M. Byrne, K. Fuqua, K. Couture, F. C. Linenburg's research found a connection with the control locus. Negative correlation is followed by self-esteem in studies (B. M. Byrne, J. G. Rosse, R. W. Boss, A. E. Johnson, D. F. Crown, W. B. Schaufeh). P. Costa and R. McCrae have developed the concept of a five-factor model of personality, which allows us to consider the connection of burnout with other personality characteristics.

Unsolved earlier part of the general problem. Initially potentially inclined to "burn out" were considered social workers, doctors and lawyers, which explained the specific features of these "auxiliary professions". Today, practically in all groups of specialists in "communicative" professions (teachers, police officers, prison staff, politicians, sales staff, insurance agents, managers, commercial banks, real estate agents, nurses, medical doctors) there are individuals with a high and intermediate level burnout" [2].

Formulating the goals of the article. The purpose of our study was to reveal the nature of the syndrome of "professional burnout" of the individual and his role in the professional activities of specialists, a comparative analysis 
of "professional burnout" from representatives of various professional groups in order to identify the professions that are most vulnerable to burnout.

Presentation of the main research material. Currently, three approaches to the definition of "burnout" syndrome are well known.

The first approach regards burnout as a state of physical, mental and, above all, emotional exhaustion, caused by longterm stay in emotionally overburdened communication situations. With this approach, "burnout" is considered approximately as a syndrome of "chronic fatigue".

The second approach regards burnout as a twodimensional model consisting, firstly, of emotional exhaustion, and secondly, of depersonalization, that is, the deterioration of the attitude to others, and sometimes to oneself.

But the most common approach is the third approach proposed by American researchers K. Maslach and $\mathrm{S}$. Jackson. They consider the "burnout" syndrome as a three-component system, which includes emotional exhaustion, depersonalization, and reduction of personal personality achievements [4].

Under emotional exhaustion, we understand the feeling of emotional devastation and fatigue that is caused by work.
De-personalization involves a cynical attitude to work and the object of his work. In particular, in the social sphere, depersonalization appears to be indifferent, inhumane, to the attitude of clients who come for treatment, counseling, education and other social services.

Finally, the reduction of professional achievements the emergence of employees feeling incompetence in their professional field, awareness of the failure in it.

The professional activity of helping specialists, the means of which is the person itself, as any other, requires the strengthening and development of certain qualities of the individual. However, the excessive development of these qualities is accompanied by changes in the structure of the personality of a specialist, which affects it negatively and even destructively. To influence on the person of the assisting specialist and stressfulness of work, high emotional load, felt by doctors, teachers, social workers and psychologists.

Data on the level of "burnout" (methodology "Diagnostics of the level of emotional burnout" by $\mathrm{V}$. V. Boyko) from representatives of different professions are given in Table 1.

Table 1

Medium-term main characteristics of "professional benefits" from representatives of various professional groups (\%)

\begin{tabular}{|l|c|c|c|}
\hline \multirow{2}{*}{ Professional group } & \multicolumn{3}{c|}{ "Professional burnout components" } \\
\cline { 2 - 4 } & Emotional exhaustion & Emotional exhaustion & Emotional exhaustion \\
\hline Teachers of schools & 22,27 & 22,27 & 22,27 \\
\hline Teachers of higher educational institutions & 19,58 & 19,56 & 19,58 \\
\hline Social workers & 22,37 & 22,36 & 22,37 \\
\hline Health care workers (doctors and nurses) & 23,18 & 23,18 & 18,18 \\
\hline $\begin{array}{l}\text { Mental health Workers (psychologists, } \\
\text { psychiatrists, psychotherapists) }\end{array}$ & 17,88 & 17,88 & 17,88 \\
\hline Legal advisers, lawyers & 22,44 & 22,43 & 22,43 \\
\hline
\end{tabular}

From the chart below, it is evident that the most prone to "burnout" are representatives of the pedagogical sphere, social workers and doctors. Teachers work in a rather restless, emotionally intense atmosphere, which requires constant attention and control over the situation of interaction in the system of "teacher-student". In such conditions, stress is caused by a multitude of stressogens that continuously accumulate in various areas of life. At the moment, the sense of control over what is happening can be crucial. If the teacher responds adequately, adaptively, he more successfully and efficiently operates and increases his functional activity and confidence, while the disadaptive reactions lead spirally down to "burnout." When requirements (internal and external) constantly dominate over resources (internal and external), a person is disturbed by the state of equilibrium. Continuous or progressive imbalance inevitably leads to "burnout".

The urgency of the problem of "burnout" of teachers is also witnessed by the activity of foreign scholars: they study the causes and consequences of the syndrome ( $\mathrm{Y}$. Gold, I. Fridman, B. Farber, G. Jenet, etc.); the appropriate psychodiagnostic toolkit is created (S. Seidman, J. Sacher, D. Chicon, R. Corf); "burnout prevention" measures are being developed and implemented (L. Thompson, J. Chick, L. Bradley, G. Par, etc.) $[1 ; 4 ; 6]$. Among the domestic scientists dealing with the problem of "professional burnout" in the pedagogical sphere, the most well-known S. D. Maksimenko, L. M. Karamushka, T. V. Zaichikova, T. V. Formanyuk, V. V. Pavlenko, N. M. Bulatevich, etc.

But, unfortunately, in studies of the degree and features of the manifestation of the syndrome of "burnout" in the teaching staff involved only workers of institutions of higher education and universities.

Differences in the degrees of "burnout" and its causes are observed not only among representatives of different professions, but also workers of different types of activities within one profession. It is established that the level of education and the specifics of the discipline that the teacher teaches give a different degree of burnout. For example, primary school teachers have a higher level of "professional burnout" than their counterparts who work with older students, music teachers are more inclined to "burnout" than teachers of mathematics, and the level of burnout in teachers of physical education is lower than in subject-teachers.

Unfortunately, there was not enough attention paid to the study of the syndrome of "burnout" from teachers working with children with disabilities in psychophysical development.

It should be borne in mind that the specialty of the teacher of a special institution for children with mental and physical defects goes beyond the traditional types of work of the teacher, since it covers: socio-pedagogical, rehab, counseling, diagnostic, psychotherapeutic, corrective and other "non-teaching" activities [10 ].

This multifaceted nature is the result of a special purpose in the professional activity of a teacher of an educational institution for children with mental retardation problems, namely: social adaptation and integration of a child with special educational needs into the modern system of social relations.

In addition, the work of pedagogical workers in educational institutions for children with mental and physical defects is complicated by many objective and subjective factors. In particular: increased tension of the nervous system; work with disadvantaged families; low salary; lack of interest and negative bias of the public, authorities, parents regarding the problems of children with mental disorders; lack of sufficient educational and methodological support for special educational institutions; certain isolation of special educational institutions, etc. 
Proceeding from this perspective, we allocate special means of prevention of a syndrome of mental burnout in the supervisor [supervisor], which uses the supervisor. The structure includes:

1. Tools for the integration and development of components of psychological competence, the experience of the internal components of the actual culture;

2. Non-therapeutic (corrective) means of counteracting emotional exhaustion;

3. Psychotherapeutic means for minimizing the symptoms of depersonalization and professional reduction;

4. Means of control and determination of the effectiveness of mastering correctional supervisor.

Modern strategies for preventing distress and burnout are a set of measures that include psychodiagnosis, audit, preventive measures and psychological intervention. Diagnosis is aimed at determining the factors of stress and stressful situations, measuring the level of stress and identifying the features that are experiencing distress.

It is necessary to develop a strategic program for managing stress and preventing adverse professional stress. The most effective prophylactic techniques:

- organization of trainings for staff on recognition of symptoms of distress, burnout and overcoming them;

- development of a staff support program, including counseling on the prevention and treatment of stressrelated ill health;

- providing flexible working schedules

- conducting practical classes in conflict management and developing interpersonal skills for employees

- increasing the attractiveness of work in the organization;

- optimization of the system of personnel motivation and stimulation

- planning of professional and career growth, etc.

Recommendations to employees to prevent occupational distress and burnout, based on the generalization of the experience of successful managers:

- it is necessary to find an interest in any, even "uninteresting" work

- treat personality mistakes as an opportunity to learn something new, as a resource for professional and personal self-perfection.

Prevention and overcoming of distress and burnout syndrome includes both self-help and the provision of external professional assistance. Within the framework of self-help, "burning" workers need to learn to understand and control distress symptoms, to master self-regulation and overcome professional ill-health. [3; 8; 9]. If help alone is not enough, in order to overcome the burnout syndrome, psychological assistance will be needed with the involvement of specialists who have methods of managing stress. It is also necessary to develop special rehabilitation programs $[5 ; 9 ; 11]$.

Conclusions. Summing up, we note that the "burnout" syndrome is a process of gradual loss of emotional, cognitive and physical energy, which is manifested in signs of emotional and intellectual exhaustion, physical fatigue, personal detachment and a reduction in the sense of satisfaction from the work performed. This syndrome is considered to be the developed person's mechanism of psychological protection in the form of partial or complete exclusion of emotions (up to the psycho-emotional "stinging"). Among professions with a high risk of a syndrome of "burnout" one of the first places occupies a teacher's profession.

Consequences of "burnout" of a teacher: deterioration of work quality; significant problems in implementing creative potential in working with children; negative interpretation of student behavior; deterioration of the mental and physical health of the teacher; increase the number of absenteeism and high turnover of personnel; increased dissatisfaction with work; lower self-confidence.

The urgency of the study of the syndrome of "professional burnout" among teachers is due to the fact that the effectiveness of its educational effect on students directly depends on the condition of the psychological wellbeing of the teacher: the emotional state of the teacher is reflected in the quality of the whole educational process.

Particular attention is required to study the syndrome of "burnout" among pedagogical workers of educational institutions for children with mental and physical disorders, due to the fact that their professional activities are deeply specific. In this regard, it is promising to identify the level and characteristics of the manifestation of the syndrome of "burnout", specific and non-specific for a given occupational group of stress factors, provoking the emergence of a syndrome of "burnout", the search for effective methods for its prevention and overcoming.

The main directions of management of professional stress, in particular prevention of distress and burnout syndrome are: informing the staff, emotional and psychological support of employees, increasing the importance of their professional activities.

The level of organizational culture and professional culture of managers has an impact on stress tolerance. To reduce organizational risk factors for the negative consequences of work stress and burnout, it is advisable to use different forms and methods to improve the psychological competence of managers and to instill the necessary health culture, high psychological stress resistance. To this end, you can use managerial and psychological counseling, business games, various psychological trainings with the complex of psychodiagnosis of organizational stress and signs of burning, and so on. within the framework of a strategic program for managing professional stress.

"Burning" workers need professional assistance in stress management and rehabilitation programs.

\section{References}

1. Bulatevych N. M. Syndrom emotsiinoho vyhoriannia vchytelia : avtoref. dys. ... kand. psykhol. nauk. - K., 2004. - 19 s.

2. Vodopianova N. S., Starchenkova E. S. Psikhicheskoe "vygoranie". Puti preodoleniia // Mir meditsiny - 2001 - № 9-10 - S. 44-45.

3. Grinberg Dzh. Upravlenie stressom: Monografiia. - SPb.: Piter, 2004. $-359 \mathrm{~s}$

4. Karamushka L. M., Zaichykova T. V. Problema syndromu "profesiinoho vyhorannia" v pedahohichnii diialnosti v zarubizhnii ta vitchyznianii psykholohii // Aktualni problemy psykholohii. Tom I. Sotsialna psykholohiia. Psykholohiia upravlinnia. Orhanizatsiina psykholohiia. - K.: Instytut psykholohii im. H. S. Kostiuka APN Ukrainy, 2002, chastyna 5. - S. 210-217

5. Malkina-Pykh I. G. Ekstremalnye situatsii : Monografiia. - M. : Eksmo, 2006. $-277 \mathrm{~s}$.

6. Orel V. E. Fenomen "vygoraniia" v zarubezhnoi psikhologii: empiricheskie issledovaniia i perspektivy // Psikhologicheskii zhurnal, 2001, tom 22, № 1, S. 99-101.

7. Pavlenko V. V. Psykholohichnyi zmist syndromu "profesiinoho vyhorannia" u vchytelia // Aktualni problemy psykholohii. Tom I. Sotsialna psykholohiia. Psykholohiia upravlinnia. Orhanizatsiina psykholohiia -K. Instytut psykholohii im. H. S. Kostiuka APN Ukrainy, 2002, chastyna 7 . S. $243-250$

8. Psikhologiia zdorovia/ pod red. G. S. Nikiforova. - SPb.: Piter, 2003. $-210 \mathrm{~s}$

9. Psikhologiia professionalnogo zdorovia : Monografiia. - SPb. : Rech, 2006. $-305 \mathrm{~s}$

10. Spetsialnaia pedagogika: Uchebnoe posobie dlia stud. vyssh. ped. ucheb. zavedenii / pod red. N. M. Nazarovoi. - M. : Izdatelskii tsentr "Akademiia", 2000. - $400 \mathrm{~s}$.

11. Stoliarenko A. M. Ekstremalnaia psikhopedagogika: Ucheb.posobie. M., 2002. $-255 \mathrm{~s}$.

Список використаних джерел

1. Булатевич Н. М. Синдром емоційного вигоряння вчителя / Наталія Миколаївна Булатевич: автореф. дис. ... канд. психол. наук. - К., 2004. -19 c.

2. Водопьянова Н. С. Психическое "выгорание". Пути преодоления / Н. С. Водопьянова, Е. С. Старченкова // Мир медицины. - 2001. № 9-10. - С. 44-45.

3. Гринберг Дж. Управление стрессом : моногр. / Дж. Гринберг. СПб. : Питер, 2004. - 359 
4. Карамушка Л.М. Проблема синдрому "професійного вигорання" в педагогічній діяльності в зарубіжній та вітчизняній психології / Л. М. Карамушка, Т.В.Зайчикова // Актуальні проблеми психології. Т. І. Соціальна психологія. Психологія управління. Організаційна психологія. - К. : Інститут психології ім. Г. С. Костюка АПН України, 2002. C. $210-217 .-4.5$

5. Малкина-Пых И. Г. Экстремальные ситуации : моногр. / И. Г. МалкинаПых. - М. : Эксмо, 2006. - 277 с.

6. Орел В. Е. Феномен "выгорания" в зарубежной психологии: эмпирические исследования и перспективы / В. Е. Орел// Психологич. журн. 2001. - Т. 22. - № 1. - С. 99-101.

7. Павленко В.В.Психологічний зміст синдрому "професійного вигорання" у вчителя / В. В. Павленко // Актуальні проблеми психології. Т. І.
Соціальна психологія. Психологія управління. Організаційна психологія. - К. : Інститут психології ім. Г. С. Костюка АПН України, 2002. С. $243-250 .-4.7$.

8. Психология здоровья / под ред. Г. С. Никифорова. - СПб. : Питер, 2003. $-210 \mathrm{c}$.

9. Психология профессионального здоровья : моногр. - СПб. : Речь, 2006. -305 c

10. Специальная педагогика : учеб. пособ. для студ. высш. пед. учеб. заведений / под ред. Н. М. Назаровой. - М. : Издательский центр "Академия", 2000. - 400 с.

11. Столяренко А. М. Экстремальная психопедагогика : учеб. пособ. / А. М. Столяренко. - М., 2002. - 255 с

Надійшла до редколегії 01.07.19

Ірина Астремська, канд. психол. наук, докторант,

Київський національний університет імені Тараса Шевченка, Київ, Україна

\section{ОСОБЛИВОСТІ ЕМОЦІЙНОГО ВИГОРЯННЯ У ФАХІВЦІВ ДОПОМАГАЮЧИХ ПРОФЕСІЙ}

У статті розглядається проблема "професійного вигорання", аналізується роль синдрому "професійного вигорання" у діяльності фахівців допомогаючих професій. Дж. Фрейденбергер, автор ідеї вигорання, відзначає, що професійне вигорання - це вичерпання енергії у людей, які працюють у сфері соціальної допомоги, коли вони відчувають, що перевантажені проблемами інших людей. Розглянуті особливості фахової діяльності педагогів та психологів освітніх закладів, що ускладнюють роботу зазначеної категорії фахівців. "Вигорання" досліджується у руслі трьох підходів: "хронічна втома", емоційне виснаження і трикомпонентна система (К. Маслахом $i$ С. Джексон). Наведено та проаналізовано дані про рівень "вигорання" представників різних професій за методикою "Діагностика рівня емоційного вигорання" В. В. Бойка.

Зосереджується увага на особливостях чинників "вигоранні" вчителів. Відзначається різниця у вигоранні вчителів різних дисциплін і різного віку учнів. Встановлено, що відмінності в ступенях "вигорання" та його причинах спостерігаються не лише у представників різних професій, а й працівників різних видів діяльності всередині однієї професії. Особливу увагу акцентовано на синдромі "професійного вигорання" серед педагогічних працівників освітніх закладів для дітей з вадами психофізичного розвитку в зв'язку з тим, що їх професійна діяльність $є$ глибоко специфічною та емоційно напруженою.

Визначено основні напрямки управління професійним стресом, зокрема профілактики дистресу і синдрому вигорання. Наведено сучасні засоби запобігання "вигоранню": психодіагностика, аудит, профілактичні заходи. Також наведено методи профілактики та подолання "вигорання": гнучкий графік роботи, проведення спеціалізованих тренінгів, професійне та кар'єрне зростання, поліпшення психологічної компетентності та прищеплення необхіної культури здоров'я.

Ключові слова: синдром "професійного вигорання", психологічний захист, педагог, психолог, професії допомоги.

Ирина Астремская, канд. психол. наук, докторант

Киевский национальный университет имени Тараса Шевченко, Киев, Украина

\section{ОСОБЕННОСТИ ЭМОЦИОНАЛЬНОГО ВЫГОРАНИЯ У СПЕЦИАЛИСТОВ ПОМОГАЮЩИХ ПРОФЕССИЙ}

Рассматривается проблема "профессионального выгорания", анализируется роль синдрома "профессионального выгорания" в деятельности специалистов помогающих профессий. Рассмотрены особенности профессиональной деятельности педагогов и психологов образовательных учреждений, затрудняющие работу указанной категории специалистов.

Особое внимание акцентировано на синдроме "выгорания" среди педагогических работников образовательных учреждений для детей с нарушениями психофизического развития в связи с тем, что их профессиональная деятельность является глубоко специфической и эмоционально напряженной.

Установлено, что различия в степенях "выгорания" и его причинах наблюдаются не только у представителей разных профессий, но и работников различных видов деятельности внутри одной профессии.

Определены основные направления управления профессиональным стрессом, в частности профилактики дистресса и синдрома выгорания.

Ключевые слова: синдром "выгорания", психологическая защита, педагог, психолог, профессии помощи.

Bulletin of Taras Shevchenko National University of Kyiv. Series "Psychology". № 1(10), pp. 13-18 (2019)

УДК 159.9

DOI: https://doi.org/10.17721/BSP.2019.1(10).3
ISSN 1728-3817

(C) Taras Shevchenko National University of Kyiv,

Publishing Center "Kyiv University", 2019

Житомирський обласний інститут післядипломної педагогічної освіти, Житомир, Україна

Ірина Бойко, канд. психол. наук, доц.

\section{ТЕОРЕТИКО-ПРАКТИЧНІ АСПЕКТИ ВИМІРЮВАННЯ ТА ОЦІНЮВАННЯ ІНТЕГРАЛЬНИХ ХАРАКТЕРИСТИК ПРОФЕСІЙНОї КОМПЕТЕНТНОСТІ ПЕДАГОГА}

Висвітлено актуальні аспекти тлумачення поняття компетенції, компетентності, їх використання та пріоритетних напрямів діагностики складових професійної компетентності педагога. Здійснено аналіз сучасних робіт із проблеми компетенції й компетентності як багатовекторності та розмаїття їх характеристик, що засвідчує дуже велику складність їх вимірювання і оцінювання; зроблено спробу пошуку шляхів рішення цієї актуальної проблеми, що пов'язана з підвищенням якості освіти у загальному контексті їі гуманізації. Метою є висвітлення окремих професійних якостей педагога: загальної спрямованість мотиваційної сфери, міри вияву особистісного відчуття професійної свободи та здібностей. Здійснено спробу більш глибше осягнути їхню специфічність за допомогою метода Роршаха. Висвітлено загальну тенденцію щодо особливостей дослідження загальної спрямованості мотиваційної сфери, міри вияву особистісного відчуття професійної свободи та здібностей, яка, на нашу думку, полягає в тому, що вона відносно автономна і сенс їі лежить у сфері з'ясування стану і тенденцій функціонування професійної свободи загалом. Подальші пошуки вбачаємо у вирішенні питання розробки ефективних методів професійної діагностики компетентності педагогів освіті та створення безперервної експериментальної системи, яка навчається на основі власних проб і помилок, коригує свої дї̈ та ініціює форми активності.

Ключові слова: компетенції, компетентність, спрямованість мотиваційної сфери, професійна свобода, здібності.

Сучасне поняття "компетенція", "компетентність" (і похідне "компетентний"), які давно використовувалися $[7 ; 14,25 ; 16]$, визнано сутністю та результатом освіти (за матеріалами ЮНЕСКО (у яких окреслюється коло компетенцій як бажаний результат). Про це свідчить аналіз сучасних робіт із проблеми компетенції та компетентності (Н. Хомський, Р. Уайт, Дж. Равен, Н.В.Кузьміна, А. К. Маркова, В. Н. Куніцина, Г. Е. Білицька, Л. І. Берестова, В.ІІ. Байденко, А. В. Хуторський, Н.А.Грішанова). Автори робіт доводять таке: а) досі у наукових колах 